\title{
First record in midwestern region of the state of São Paulo, Brazil of Typhlops brongersmianus Vanzolini, 1976 (Squamata: Typhlopidae)
}

\author{
Mauricio Papa de Arruda ${ }^{1^{*}}$, Carlos Henrique L. N. Almeida ${ }^{2}$, Daniel C. Rolim ${ }^{3}$ and Fábio Maffei ${ }^{3}$ \\ 1 Universidade Estadual de Campinas (UNICAMP), Instituto de Biologia, Departamento de Anatomia, Biologia Celular e Fisiologia e Biofísica. CEP \\ 13083-863. Campinas, SP, Brasil. \\ 2 Universidade Estadual de Campinas (UNICAMP), Instituto de Biologia, Museu de Zoologia “Prof. Adão José Cardoso”. CEP 13083-863. Campinas, \\ SP, Brasil. \\ 3 Universidade Estadual Paulista (UNESP), Instituto de Biociências de Botucatu, Departamento de Zoologia. Distrito de Rubião Jr. CEP 18618-000. \\ Botucatu, SP, Brasil \\ * Corresponding author. E-mail: arrudabio@gmail.com
}

\begin{abstract}
In this study we report on two new records of the blindsnake Typhlops brongersmianus for the municipality of Bauru, midwestern region of the state of São Paulo, Brazil. These records expand the geographic distribution currently known for this species in the state and contribute to the knowledge of snakes in southeastern Brazil.
\end{abstract}

The Typhlopidae, commonly referred to as wormsnakes or blindsnakes, is the largest family of the Scolecophidia, with 215 species occurring in tropical and subtropical regions of Americas, Africa, Asia, and Australia. Of this diversity, more than $70 \%$ of the species in the family belong to the genus Typhlops (Greene 1997). According to Bérnils (2010), in Brazil this family is represented by six species: Typhlops amoipira Rodrigues and Juncá, 2002, T. brongersmianus Vanzolini, 1976, T. minuisquamus Dixon and Hendricks, 1979, T. paucisquamus Dixon and Hendricks, 1979, T. reticulatus (Linnaeus, 1758), and T. yonenagae Rodrigues, 1991.

The blindsnake Typhlops brongersmianus is a large species within the family Typhlopidae (maximum total length $325 \mathrm{~mm}$ ), with brown, yellowish brown or reddish brown coloration (Dixon and Hendricks 1979). This species is the most widespread member of the genus in South America, occurring from Uruguay to Venezuela (Lema 1982, 1987), and is found in a diversity of habitats, including deforested areas (Strüssmann and Sazima 1993) and agricultural lands (Marciano-Jr. et al. 2010). In Brazil, T. brongersmianus is found in several biomes throughout almost the entire territory (Rodrigues and Juncá 2002). Despite being a species with many records and widely distributed in Brazil, new records that fill long gaps still exists between localities, provide information relevant to population and phylogeographic studies.

We report here on the first record of T. brongersmianus in midwestern region of the state of São Paulo, southeastern Brazil, in the municipality of Bauru, where the predominant vegetation is cerrado (the Brazilian savanna), with small areas of seasonal semi-deciduous forest (a subtype of Atlantic forest) (Nóbrega and Prado 2008). The species was encountered during fieldwork conducted in the region from September, 2010 to February, 2011, with a sampling effort of five days per month. Three specimens were observed in total in two localities separated by only 3.5 kilometers. The first site is located in Jardim Botânico,

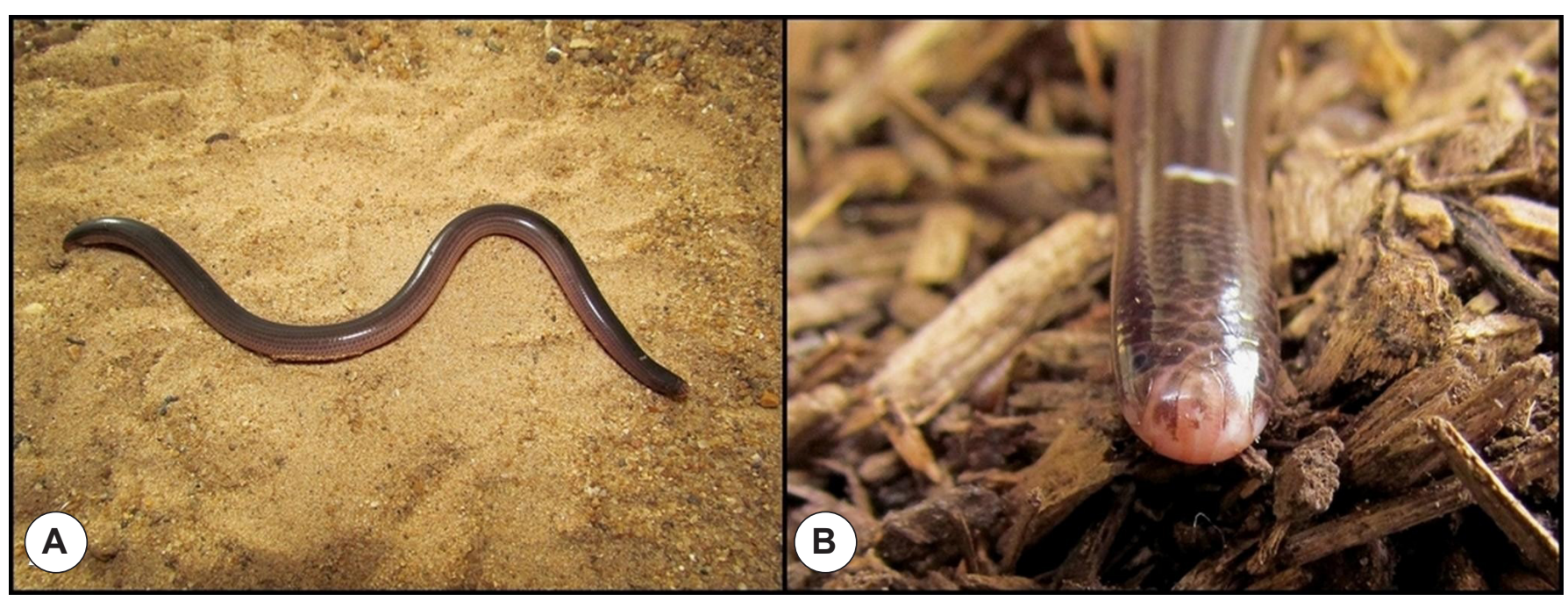

FIGURE 1. Typhlops brongersmianus (ZUEC-3541; snout-vent length $205 \mathrm{~mm}$; tail length $5 \mathrm{~mm}$ ). Dorsal (A) and head (B) views of the specimen collected in the Jardim Botânico, municipality of Bauru, São Paulo, Brazil. 
in the Municipality of Bauru (22²0’59” S, $49^{\circ} 01^{\prime} 03^{\prime \prime}$ W, $568 \mathrm{~m}$ elevation), where two individuals were captured in pitfall traps. This site occupies 321.71 ha, is protected, and is predominantly composed of cerrado vegetation (sensu lato) (Nobrega and Prado 2008). The animals were captured in a shrub savanna area (dirty field), near the Vargem Limpa stream. The soil is sandy, wet, and covered by herbaceous vegetation and bushes among some scattered trees. The stream is roughly $1 \mathrm{~m}$ in width, and spans across a valley in an open area surrounded by vegetation characterized as savanna woodland. The second site is located in Instituto Lauro de Souza Lima (2220'22" S, 4858'60" W, 529 m elevation), where we visually recorded one specimen that was not collected. The blindsnake was observed at 18:30 hours, on the edge of the dam in an open area of grass. This area is a protected reserve with 217.42 hectares with a similar floristic composition with the first locality (savanna woodland). The observations that the species exhibit a preference for sandy soils are consistent with those reported by Freitas (2003).

Photographs were made of one individual from Jardim Botânico, municipality of Bauru (Figure 1) that was collected and deposited in the Museum of Zoology "Prof. Adão José Cardoso" Universidade Estadual de Campinas,
UNICAMP (ZUEC-3541). The taxonomic identification was made in accordance with Dixon and Hendricks (1979). A map with new geographic distribution and previous records of literature is provided, obtained with DIVA-GIS software (Figure 2).

The historical records of $T$. brongersmianus geographically close to these new observations are separated by distances of $174 \mathrm{~km}$ to the east (municipality of Pirassununga), $197 \mathrm{~km}$ to the north (municipality of Barretos), and $320 \mathrm{~km}$ to the west (municipality of Presidente Epitácio), all municipalities belonging to the state of São Paulo (Martins et al. 2010), and $238 \mathrm{~km}$ to the south in the state of Paraná, municipality of Londrina (Bernarde and Machado 2002). Thus, the new records presented in our study fills a gap between these populations of T. brongersmianus, in one of the most inventoried areas of Brazil, and represents the first record for the Cerrado region of the state of São Paulo (Zaher et al. 2011). Likely due to their secretive, fossorial nature, observations in the wild are not common. Despite the widespread distribution of the T. brongersmianus in South America, little is known about their biology (Avila et al. 2006), and the new population records in different biomes are important to future population and phylogenetic studies, as well as conservation assessments of the species.

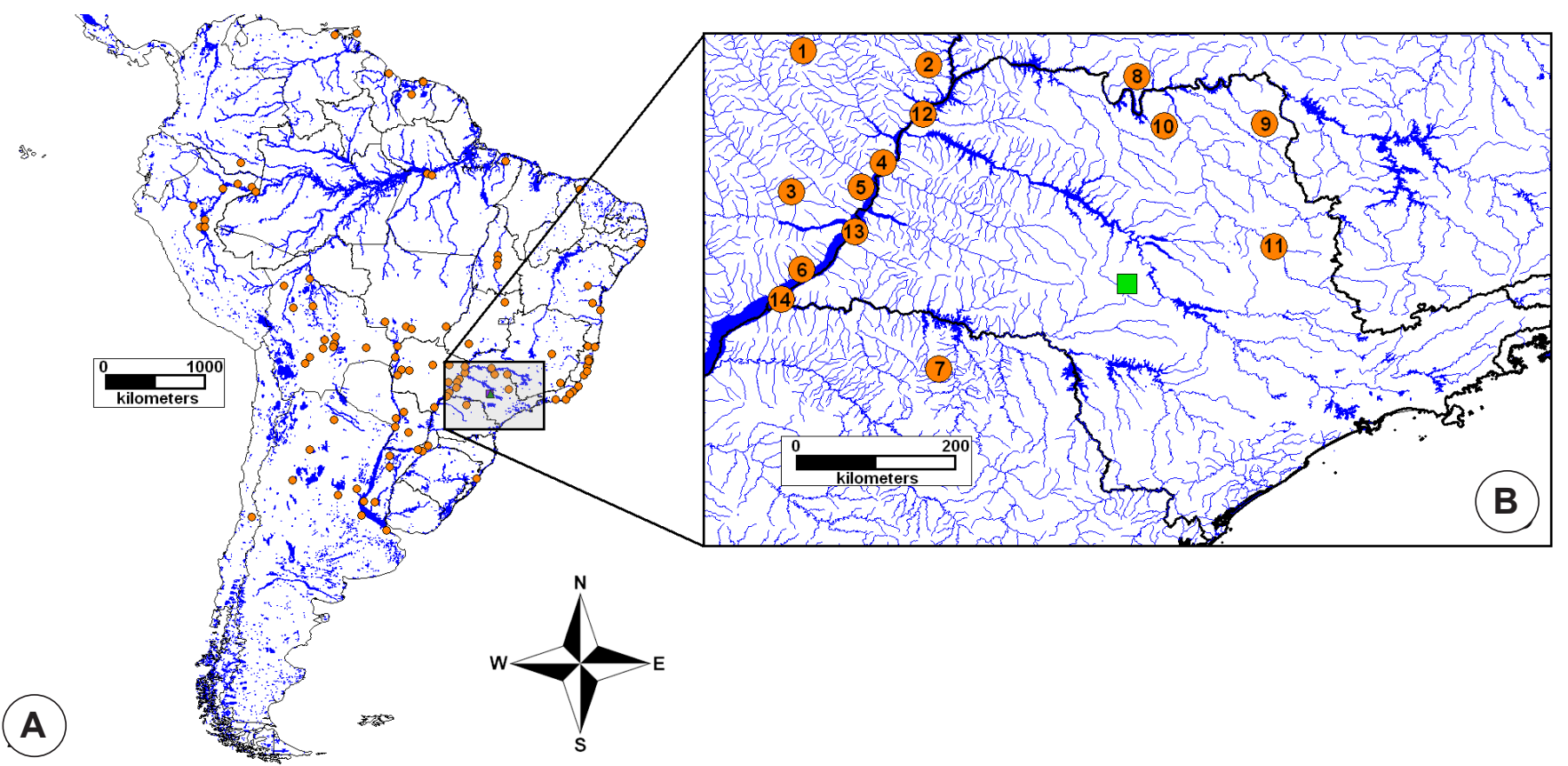

FigURE 2. (A) Distribution of T. brongersmianus in South America (orange circles) according to published records; (B) New record (green square) and nearest populations. 1 - Água Clara; 2 - Aparecida do Taboado; 3 - Santa Rita do Pardo; 4 - Três Lagoas; 5 - Brasilândia; 6 - Anaurilândia; 7 - Londrina; 8 - Frutal; 9 - Franca; 10 - Barretos; 11 - Pirassununga; 12 - Ilha Solteira; 13 - Presidente Epitácio; 14 - Rosana. 1-6 populations located in the state of Mato Grosso do Sul; 7 and 8 population located in the state of Paraná and Minas Gerais, respectively; 9-16 populations located in the state of São Paulo.

\begin{abstract}
ACKNOWLEDGMENTS: We are grateful to the Instituto Lauro de Souza Lima, to the Director of the Jardim Botânico Municipal de Bauru, Luiz Carlos de Almeida Neto, by permissions to the fieldworks and IBAMA to the research license (SISBIO 22419-2). We would like to thank also to Paulo Roberto Manzani for assistance in identification of the species and William Pinheiro da Costa by helpful in field work. Our research was supported by the Fundação de Amparo à Pesquisa do Estado de São Paulo (FAPESP) through grant 2010/06915-2 and 2010/08291-6 (M. P. Arruda).
\end{abstract}

\section{Literature Cited}

Avila, R.W, F.L. Vanda and S.B. Vanessa. 2006. Biology of the blindsnake Typholops brongersmianus (Typhlopidae) in a semideciduous Forest from Central Brazil. Herpetological Journal 16: 403-405
Bernarde, P.S. and R.A. Machado. 2002. Fauna reptiliana da Bacia do Rio Tibagi. p. 291-296 In M.E. Medri, E. Biachini, O.A. Shibatta, and J.A. Pimenta (ed.). A Bacia do rio Tibagi. Londrina: MC-Gráfica.

Bérnils, R.S. (org.). 2010. Brazilian reptiles - List of species. Electronic Database accessible at http://www.sbherpetologia.org.br/. Sociedade Brasileira de Herpetologia. Captured on 12 March 2011.

Dixon, J.R. and F.S. Hendricks. 1979. The wormsnakes (family Typhlopidae) of the Neotropics, exclusive of the Antilles. Zoologische Verhandelingen 173: 1-39.

Greene, H.W. 1997. Snakes: the evolution of mystery in nature. Berkeley: University of California Press. 351p.

Freitas, M.A. 2003. Serpentes brasileiras. Bahia: Lauro de Freitas. 160 p. Lema, T. 1982. Sobre a ocorrência de Typhlops brongersmianus Vanzolini, 1972, no Estado do Rio Grande do Sul e regiões adjacentes (Serpentes, 
Typhlopidae). Iheringia, Série Zoologia 61: 3-7.

Lema, T. 1987. Lista preliminar das serpentes registradas para o Estado do Rio Grande do Sul (Brasil Meridional) (Reptilia, Lepidosauria, Squamata). Acta Biologica Leopoldensia 9(2): 225-240.

Linnaeus, C. 1758. Systema naturæ per regna tria naturæ, secundum classes, ordines, genera, species, cum characteribus, differentiis, synonymis, locis. Tomus I. Editio decima, reformata. Stockholm: Laurentii Salvii, Holmiæ. 824 p.

Marciano Jr., E., J.A. Jesus and M. Solé. 2010. Typhlops brongersmianus (Brongersma's Threadsnake). Reproduction. Herpetological Review 41(1): 100.

Martins, R.L., A.L. Silveira and S.F. Bruno. 2010. New records of Typhlops brongersmianus (Serpentes, Typhlopidae) in southeastern Brazil. Herpetology Notes 3: 247-248.

Nóbrega, G.A. and J. Prado. 2008. Pteridófitas da vegetação nativa do Jardim Botânico Municipal de Bauru, Estado de São Paulo, Brasil. Hoehnea 35(1): 7-55.

Rodrigues, M.T. 1991. Herpetofauna das dunas interiores do rio São Francisco, Bahia, Brasil. 4. Uma nova espécie de Typhlops (Ophidia, Typhlopidae). Papéis Avulsos de Zoologia 37(22): 343-346.
Rodrigues, M.T. and F.A. Juncá. 2002. Herpetofauna of the quaternary sand dunes of the middle Rio São Francisco: Bahia: Brazil. VII. Typhlops amoipira sp. nov., a possible relative of Typhlops yonenagae (Serpentes, Typhlopidae). Papéis Avulsos de Zoologia 42(13): 325333.

Strüssmann, C. and I. Sazima. 1993. The assemblages of the Pantanal at Poconé western Brazil: faunal composition and ecology summary. Studies on Neotropical Fauna and Environment 28: 157-168.

Vanzolini, P.E. 1976. Typhlops brongersmianus, a new name for Typhlops brongersmai Vanzolini, 1972, preoccupied (Serpentes, Typhlopidae). Papéis Avulsos de Zoologia 29: 247.

Zaher, H., F.E. Barbo, P.S. Martínez, C. Nogueira, M.T. Rodrigues and R.J. Sawaya. 2011. Répteis do Estado de São Paulo: conhecimento atual e perspectivas. Biota Neotropica 11(1a): 1-15.

RECEIVED: April 2011

LAST REVISED: July 2011

ACCEPTED: July 2011

Published ONLINE: July 2011

EDITORIAL RESPONSIBILITY: Cameron Siler 